\title{
Light Microscopy for Teaching-Learning in Histology Practical in Undergraduate Medical Education of Bangladesh-a Teachers' Perspective
}

\author{
Ahmed, R. ${ }^{1}$, Shamim, K.M. ${ }^{2}$, Talukdar, H.K. ${ }^{3}$, Parvin, S. $^{4}$
}

\begin{abstract}
Objectives: This study was aimed at looking into the perceptions of Bangladeshi teachers of Anatomy regarding the advantages and disadvantages of using glass slide and microscope in the teachinglearning of Histology in the practical classes at the undergraduate level of medical education in Bangladesh.
\end{abstract}

Methods: Interviews were carried out with 21 teachers of Anatomy from ten medical colleges of Bangladesh from January to December, 2014.

Results: The interviewee teachers identified five basic advantages of traditional light microscopy in the teaching-learning of practical Histology. They were: positive psychological impact on students, contributions in long-time memorization of topics, development of practical skills and development of diagnostic capability, and direct one-to-one contact. The five basic disadvantages identified were: difficulty in understanding by the students, difficulty in guidance and feedback, inadequacy of good slides, difficulty in arranging revision classes and discomfort in handling microscopes. Use of computer-based supporting aids has been suggested for improving the teaching and learning.

Conclusions: Study findings revealed several advantages and disadvantages of traditional light microscopy based practical Histology teaching-learning as perceived by the teachers. Suggestions regarding improvement through blending computer based supporting aids to the traditional light microscopy were also noted.

Key words: Histology practical, microscope, teacher

\section{Introduction}

Histology, a major discipline within the medical and other life science curricula, is based on theoretical didactical strategies as well as on practical training.

\footnotetext{
${ }^{1}$ Department of Anatomy, Tangail Medical College, Tangail, Bangladesh.

${ }^{2}$ Department of Anatomy, Banghabandhu Sheikh Mujib Medical University, Dhaka, Bangladesh.

${ }^{3}$ Centre for Medical Education, Mohakhali, Dhaka

${ }^{4}$ Department of Biochemistry, Sir Salimullah Medical

College, Dhaka, Bangladesh.
}

Corresponding Author:

Dr. Rukshana Ahmed

Associate Professor, Anatomy

Tangail Medical College, Tangail, Bangladesh.

Email:rukshanakahmed@yahoo.com

DOI: http://doi.org/10.4038/seajme.v12i1.39
The laboratory has always been an excellent setting where group(s) of students learn to work together as team(s), working through and discussing problems as they proceed (Drake, 1998). Ideally, teaching in the laboratory allows sufficient time for learning, practice and feedback (Cox \& Ewan, 1982).

The practical classes in Histology are aimed at teaching learners to identify different cells and tissues. The reason behind this is that learners must know what normal tissues and cells look like so that they can recognise pathological tissues (Ackermann, 2004) and draw the structure-function relationships.

In some countries like India, medical institutions consider light microscopy as the principal teaching-learning tool for conduction

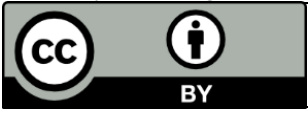

26

SEAJME. This is an Open Access article distributed under the terms of the Creative Commons Attribution License (http://creativecommons.org/licenses/by/4.0/), which permits unrestricted use, distribution, and reproduction in any medium, provided the original author and source are credited 
of Histology practical classes (Anand \& Pushpa, 2016). On the other hand, some institutions in different parts of the world like the University of Michigan, have demonstrated a strong preference for electronic rather than traditional learning resources (Holaday et al., 2013).

In some other medical schools, for example, some in the United States, use of mixture of light microscopy and web-based approaches are practiced (Bloodgood \& Ogilvie, 2006). In Bangladesh, light microscopy remains the primary instructional tool in Histology practical classes. In Bangladesh, Histology practical classes are usually conducted in two sessions:

- A tutorial is presented with thorough descriptions of the structures of the tissues. During discussion, the instructor uses Histology atlases, books, laminated and enlarged reproductions of illustrations (drawings, photomicrographs), poster boards, chalkboard or white board. In a few institutions, slide projection, multimedia presentation, computer monitor-based demonstration or OHP presentation are used.

- The learners then view microscopic slides of cross-sections through tissues) under a light microscope under the guidance of the instructor.

For many years, the teaching of Histology or Microanatomy has relied on banks of light microscopes and boxes of histological glass slides. This gives students an opportunity to learn how to operate a light microscope. However, this approach suffers from a great variability in the quality of the slide material. In addition, it is difficult to get many tissues and organ preparations. Moreover, glass slides are inherently breakable and liable to fading. Apart from that, the upkeep of so many light microscopes is a continuous expense (Hortsch, 2013). On the other hand, it is difficult to determine whether the learner would remember the image that he has seen under the microscope for long. Ackermann (2004) in his study mentioned that if a learner looks at a tissue or structure in February for two or three minutes, it is doubtful whether the learner will recognize that structure in the October practical exam if no reinforcement had taken place in the meantime. Finding and identifying cells and tissues on a microscopic slide is time consuming. Learners' often waste time looking for structures and cells under the microscope which they may not even find or identify correctly. In the same study, Ackerman (2004) revealed that many learners do not even look for the tissues and structures under the microscope but attend the practical purely for the sake of the accompanying tutorial. Finding shows that majority of students indicated attending practical as their least favourite way of studying Histology. Personal experience of the present researcher and informal discussion with the teachers of Histology tells a similar story regarding many Bangladeshi students, pointing at lack of attention and low energy level during practical work.

In the later part of the $20^{\text {th }}$ century and the beginning of the $21^{\text {st }}$ century, there has been a rapid acceleration in the use of computers and the web in medical school teaching. In medical schools in the United States, in terms of the tools used in Histology laboratory, there has been a dramatic increase in the use of various forms of computer aided instruction (Bloodgood \& Ogilvie, 2006). At the school of Medicine of the University at Buffalo, half of the laboratory exercises that would have been performed with a microscope were performed instead with interactive computer application even in 2001(Cotter, 2001).

The shift from glass slides and microscopes to computer images is being driven by the notion that computers, in addition to many other positive attributes, are very efficient for students to learn visual material (Harris et al., 2001).

The question therefore arises: can the microscope be replaced by images displayed on a monitor? Ackermann (2004) maintains that the microscope qualifies as a cognitive tool in teaching and learning because using a microscope for learning provides a constructive learning environment which allows learners to construct their own knowledge rather than absorbing information given to them. The microscope challenges and stimulates deep reflective thinking that brings about meaningful learning, the author adds. In Krippendorf \& Lough's study (2005), students felt that the use of light microscope should be taught at some point in the curriculum.

Considering the potential of computer-based Histology teaching and in the face of the shortage of teachers compared to the growing number of medical colleges (medical schools), it is reasonable to revisit the instructional methods in Histology practical classes in Bangladesh. There is a need to assess if the materials and the methods used for 
instructions in Histology practical are accomplishing the intended objectives. Teachers' perceptions in this regard can expose the weaknesses and point out the strengths of the traditional use of the light microscopy and suggest viable alternatives if required. Such insight into the issue can then be used to fix problems and to improve the instructional system. The present study was aimed at looking into the perceptions of Bangladeshi teachers in Anatomy regarding the advantages and disadvantages of using glass slide and microscope in the teachinglearning of Histology in the undergraduate medical courses of Bangladesh.

\section{Methods}

A qualitative study was undertaken over a period of one year, January 2014 to December 2014 , in ten purposively selected medical colleges (four government and six nongovernment) of Bangladesh. A total of 21 Histology teachers having more than one year of teaching experience and being engaged in teaching in Histology practicals were selected through convenient sampling and were enrolled for an interview asking two questions:

- What is your opinion regarding the advantages of light microscope and glass slides (traditional light microscopy) in undergraduate teaching-learning in Histology practical classes?

- What is your opinion regarding the disadvantages of traditional light microscopy in undergraduate teachinglearning in Histology practical classes?

Face to face interviews were taken by the researcher herself. Each interview took 40 to 45 minutes and was recorded with an audio recorder. The important points made by the interviewees were also noted down. From the recordings, a written transcript was prepared. Content analysis of the transcript was then done to bring out important points of the interviewees statements.

Necessary prior permissions were taken from the principals of the involved medical colleges. Voluntary participation was ensured by taking verbal consent of the participants. It was explained to them that the findings of the study will be used only for the research purpose and confidentiality and anonymity of the responses would be maintained.

\section{Results}

All the teachers felt that use of microscopes and glass slides has got some advantages (over the use of drawings and photomicrographs). However, there are some disadvantages as well.

\section{Advantages identified}

\section{Positive psychological impact on students}

Most of the respondents believed that viewing of real tissue under microscope would create a positive psychological impact in the students' mind.

\begin{abstract}
"My students are observing real tissues under the microscope. Experience with real thing obviously creates a positive psychological effect upon them".
\end{abstract}

\section{Long-time memorization of topics}

Some interviewees perceived that microscopic viewing would help in long term memorization of the histological structure viewed.

"Students are watching original tissue; that's why they find more interest (than they would without using microscope) and that would lead to long time memorization".

\section{Development of practical skill}

Some of the participants pointed out that the skill of operating light microscope would be helpful in students' future fields of work; learning of this skill would build confidence in them.

"Handling microscopes is a useful skill. This skill would act as a support and would build confidence. It would help students when they will be in their practical fields of work".

\section{Development of diagnostic capability}

Some viewed that practice with real features helps the students to cope up with actual findings.

"Microscopes and glass slides are more realistic than drawings (or photomicrographs). If a student gets idea about the real slide (section), it would help him in his future fields of work". 
"Handling microscope and glass slides and searching for desired tissue develop enquiring ability within them (students)".

Direct one-to-one contact

Some considered that this teaching-learning tool would provide direct one-to-one contact between the instructor and the student.

"While watching slides by themselves, sometimes they cannot identify the desired structure. They ask for help from the instructor, and the instructor responds by clarifying individual confusions".

\section{Disadvantages identified}

\section{Difficulty in understanding by students}

A group of teachers opined that students face difficulties in proper understanding of the histological structures with microscopic viewing of histological slides at low magnifications. They often fail to find exact similarities with the features found in the illustrations in textbooks (or atlases) or with those showed in classes.

"Students are not getting interest in viewing the slides under microscope as because they (often) cannot find similarities between the features identifiable at power 10x and the information being provided to them in lecture classes and in textbooks".

\section{Difficulty in guidance and feedback}

Some teachers told that they faced difficulties in providing individual active guidance to students in the practical work of viewing histology slides under microscope.

"Although I want to, it is not possible for me to show all the slides under microscope individually to all the students. (For doing so), I would need another supporting aid by my side".

"It is not possible for me from the other side of the microscope (i.e., not viewing the slide simultaneously) to realize whether students are able to identify specific structures on the slides or not".

\section{Inadequacy of good slides}

Some faculty mentioned about the inadequacy of good quality slides and unavailability of alternatives.
"(Sometimes,) the slide is so bad; I am telling my students that stomach is composed of four layers but I cannot show them all those layers".

"If Internet and multimedia were present (in the class) then I could download histological pictures and show them to my students".

\section{Difficulty in arranging revision classes}

Some pointed out that they faced difficulty in arranging revision classes with direct observation under microscope.

"We face difficulties in giving revision classes through traditional system. With virtual microscopy, it will be much easier to arrange such revision classes".

\section{Discomfort in handling microscopes}

Some figured out that chance of breaking glass slides made the students uninterested in handling microscopes as much as they should.

"Students have to pay for if they break a slide. (Therefore) they have hesitation in handling microscopes and don't want to explore much for the histological features present on the supplied slides".

\section{Discussion}

The interview findings of the present study show that according to the teacherrespondents, the use of glass slides and microscopes in the teaching-learning of undergraduate Histology practicals has got some advantages as well as some disadvantages. Most of them believed that getting idea of the real tissue on the slide creates a positive psychological impact. Some opined that learning microscopic skill would be helpful for the future fields of work of the students. Harris et al., (2001) mention that many anatomy and pathology educators believe that viewing slides of human tissue under the microscope adds a totally different dimension to learning that is not afforded by still images. The study by Krippendorf and Lough (2005) included a survey of twelve faculty members involved in Histology laboratory teaching. One of these participants asserted, "I prefer the less sterilized view obtained with microscope and glass slides because the experience reveals the difficulties that underlie the interpretation of images. I believe the struggle in their training makes them better doctors by challenging them to 
separate fact and bad artifact and more fully understand how much weight they can put on microscopic results when determining the diagnosis and recommending treatment".

Teachers of Histology course at the School of Medicine and Biomedical Sciences at SUNY at Buffalo believed that medical students should learn to interpret histological material with a microscope (Cotter 1997). Hortsch (2013) believes that "students need to learn the intricacies of manipulating a light microscope and appreciate the variability of the biological material they have at their disposals". Pratt (2009) considers that the knowledge of using light microscope not only applies to research but also to some clinical settings. The author mentions in this regard the practices and hospitals where digital technology is not available or to routine procedures like those in an obstetric and gynaecological practice. By operating a microscope, students would learn how to understand what they see. Cotter (2001) believes that for "sharpness, depth of focus and overall clarity of a section", direct observation under a microscope has no substitute. Survey results (Bloodgood \& Ogilvie, 2006) received from 82 medical schools (79 being US medical schools) showed that, at that time around, $71 \%$ of schools utilized microscopes in Histology laboratory teaching and $66 \%$ planned to continue doing so during the next administration of the course.

Regarding the disadvantages of microscope and glass slides, most of the teachers participating in the present study felt that students are not getting interest in practical classes with optical microscopy. Some teachers expressed their difficulties with this traditional method while providing supervision and getting feedback and giving revision classes. Study findings of Wader et al.(2014), which was a questionnaire-based survey undertaken at Krishna Institute of Medical Sciences, Maharastra, India, among $1202^{\text {nd }}$ year undergraduate medical students and eight tutors on a structured Likert scale show that actual microscopy slides received a low rating from both the tutors and students. Those tutors expressed that in a traditional situation it is difficult to track learner's active participation and progress as well. Moreover, the maintenance of a large number of microscopes and of reasonable number of glass slides make this approach "a constant financial drain on any educational institution". Hotsch (2013) pointed at the variability in the quality of sections as well as the relative unavailability of glass slides of many tissues (especially of human origin) as important drawbacks. Anyanwu et al., (2012) feel that the cumbersome process and limitations associated with the viewing with light microscope and the problems of achieving, movement, and replacement of glass slides have become a challenge in the teaching of Histology and also the assessment of student performance. These findings are in line with the present study findings.

There was a time when apart from the microscopic slides there was only availability of static illustrations (drawings and photomicrographs) of histological structures at different magnifications. One couldn't navigate beyond the part presented in these illustrations. There was no scope for focusing these illustrations at higher or lower powers either. But "Virtual microscopy" came up with both these facilities. Microscopic slides are photographed digitally, and software's are used to equip them with these facilities. This makes the histological section digitally available to any student even outside the classroom. Therefore, they can access these 'slides' at their own times and own paces. In addition, the navigability and magnificationchanging facilities parallel the use of virtual microscopy in histopathological examinations as Pathology students in later years of the course and as career histopathologist for some in future.

Important conclusions from the survey done by Bloodgood and Ogilvie in 2006 about the use of various technologies in Histology laboratory teaching was that the most schools in the US were using a mixture of teaching tools in their Histology laboratory instruction. The clear trend has been towards a blending of the new computer based instructional technologies like virtual microscopy with the long-standing use of microscopes and glass slides.

\section{Conclusion}

The educational goal of this study was to find out teachers' opinion regarding the advantages and disadvantages of traditional light microscopy in Histology practical teaching and learning of the undergraduate medical courses of Bangladesh. Several advantages and disadvantages as perceived by the teachers were identified. Suggestions have been noted about how computer based supporting aids can be blended with the traditional microscopy for improving the present strategy. 


\section{Acknowledgement}

We sincerely appreciate the cordial help and cooperation from the respected principals of the ten medical colleges and thank them. We were indebted to all the Anatomy teachers who had so cordially given us time despite their busy schedules.

\section{References}

Ackermann, P.C., (2004) The suitability of a multimedia resource for teaching undergraduate histology in a developing country, Thesis (PhD), University of Pretoria.

Anand, A.V. \& Pushpa, N.B. (2016) Innovation in histology practical demonstration: Students and teachers view point, International Journal of Anatomy and Research, 4, 2, pp. 2469-2472.

Anyanwu, G.E., Agu, A.U. \& Anyaechie, U.B. (2012) Enhancing learning objectives by use of simple virtual microscopic slides in cellular physiology and histology: impact and attitudes, Advances in Physiology Education, 36, 2, pp. 158-163.

Bloodgood, R.A. \& Ogilvie, R.W. (2006) Trends in histology laboratory teaching in United States medical schools, Anatomical Record (Part B New Anatomist), 289, 5, pp. 169-175.

Cotter, J.R. (1997) Innovations in medical student education: computer assisted instruction for the medical histology course at SUNY at Buffalo, Academic Medicine, 72, 10, pp. S124-S126.

Cotter, J.R. (2001) Laboratory instruction in histology at the University at Buffalo: recent replacement of microscope exercises with computer applications, Anatomical Record, 265, 5, pp. 212-221.

Cox, K.R. \& Ewan, C.E. (1982) The Medical Teacher, New York: Churchill Livingstone.

Drake, R.L. (1998) Anatomy education in a changing medical curriculum, Anatomical Record, 253, pp. 28-31.
Hariss, T., Leaven, T., Heidger, P., Kreiter, C., Duncan, J. \& Dick, F. (2001) Comparison of a virtual microscope laboratory to a regular microscope laboratory for teaching histology, Anatomical Record (New Anatomist), 265, 1, pp. 10-14.

Holaday, L., Selving, D., Purkiss, J. \& Horsth, M. (2013) Preference of interactive electronic versus traditional learning resources by university of Michigan medical students during the first year histology component, Medical Science Educator, 23, 4, pp. 607-619.

Hortsch, H.M. (2013) From microscopes to virtual reality- how our teaching of histology is changing, Journal of Cytology and Histology, 4, 3, pp. 1-3.

Jacyna, L.S. (200I) A host of experienced microscopist: the establishment of histology in nineteenth century Edinburgh, Bulletin of the History of Medicine, 75, 2, pp. 225-253.

Krippendorf, B.B. \& Lough, J. (2005) Complete and rapid switch from light microscopy to virtual microscopy for teaching medical histology, Anatomical Record (Part B New Anatomist), 285, 1, pp. 19-25.

Paulsen, F.P., Eichhorn, M. \& Brauer, L. (2010) Virtual microscopy- the future of teaching histology in the medical curriculum? Annals of Anatomy, 192, 6, pp. 378-382.

Pratt, R.L. (2009) Are we throwing histology out with the microscope? A look at histology from the physicians' perspective, Anatomical Science Education, 2, 5, pp. 205-209.

Wader, J.V., Kumbhar, S.S. \& Mankar, D.V. (2014) An appraisal of innovation in practical teaching in anatomic pathology-a students' and teachers' perspective, Al Ameen Journal of Medical Science, 7, 1, pp. 58-64. 